\title{
ON SP-ITERATION SCHEMES FOR MULTI-VALUED MAPPINGS IN CAT(0) SPACES
}

\author{
KRITSANA SOKHUMA \\ Department of Mathematics, Faculty of Science and Technology \\ Phranakhon Rajabhat University, Bangkok 10220, Thailand \\ E-mail: k_sokhuma@yahoo.co.th
}

\begin{abstract}
In this paper, we extend known results on convergence of SP-iterations to fixed points of nonexpansive single-valued mappings to a multi-valued version. In order to do so, we prove strong convergence theorems for SP-iteration schemes involving quasi-nonexpansive multi-valued mappings in the framework of CAT(0) spaces.

Key Words and Phrases: Multi-valued nonexpansive mappingsm SP-iteration process, strong convergence, $\mathrm{CAT}(0)$ spaces.
\end{abstract}

2010 Mathematics Subject Classification: 47H09, 47H10, 49M05

\section{REFERENCES}

[1] A. Abkar, M. Eslamian, Convergence theorems for a finite family of generalized nonexpansive multi-valued mappings in CAT(0) spaces, Nonlinear Anal., 75(2012), 1895-1903.

[2] M. Bridson, A. Haefliger, Metric Spaces of Non-positive Curvature, Springer, Berlin, 1999.

[3] F. Bruhat, J. Tits, Groupes réductifs sur un corps local: I. Données radicielles valuées, Publ. Math. Inst. Hautes Études Sci., 41(1972), 5-251.

[4] R. Dewangan, B.S. Thakur, M. Postolache, Strong convergence of asymptotically pseudocontractive semigroup by viscosity iteration, Appl. Math. Comput., 248(2014), 160-168.

[5] S. Dhompongsa, A. Kaewkhao, B. Panyanak, Lim's theorems for multi-valued mappings in CAT(0) spaces, J. Math. Anal. Appl., 312(2005), 478-487.

[6] S. Dhompongsa, B. Panyanak, On $\Delta$-convergence theorems in CAT(0) spaces, Comput. Math. Appl., 56(2008), 2572-2579.

[7] W. Laowang, B. Panyanak, Strong and $\Delta$-convergence theorems for multi-valued mappings in CAT(0) spaces, J. Inequal. Appl., 2009, Article ID 730132.

[8] B. Panyanak, Mann and Ishikawa iterative processes for a multi-valued mappings in Banach spaces, Nonlinear Anal., 70(2009), 1547-1556.

[9] R.P. Pathak et al., On Noor-type iteration schemes for multi-valued mappings in CAT(0) spaces, Fixed Point Theory Appl., 2015(2015):133.

[10] W. Phuengrattana, S. Suantai, On the rate of convergence of Mann, Ishikawa, Noor and SPiteration for continuous functions on an arbitrary interval, J. Comput. Appl. Math., 235(2011), 3006-3014.

[11] K.P.R. Sastry, G.V.R. Babu, Convergence of Ishikawa iterates for a multi-valued mapping with a fixed point, Czech. Math. J., 55(2005), 817-826.

[12] N. Shahzad, Invariant approximations in CAT(0) spaces, Nonlinear Anal., 70(2009), 4338-4340. 
[13] N. Shahzad, Fixed point result for multimaps in CAT(0) space, Topol. Appl., 156(2009), 9971001.

[14] N. Shahzad, J. Markin, Invariant approximations for commuting mappings in hyperconvex and CAT(0) spaces, J. Math. Anal. Appl., 337(2008), 1457-1464.

[15] N. Shahzad, H. Zegeye, On Mann and Ishikawa iteration schemes for multi-valued maps in Banach space, Nonlinear Anal., 71(2009), 838-844.

[16] Y. Song, H. Wang, Erratum to "Mann and Ishikawa iterative processes for multi-valued mappings in Banach spaces", Comput. Math. Appl., 55(2008), 2999-3002.

[17] Y. Song, H. Wang, Convergence of iterative algorithms for multi-valued mappings in Banach spaces, Nonlinear Anal., 70(2009), 1547-1556.

[18] S. Suantai, Weak and strong convergence criteria of Noor iteration for asymptotically nonexpansive mappings, J. Math. Anal. Appl., 311(2005), 506-517.

[19] K.K. Tan, H.K. Xu, Approximating fixed points of nonexpansive by the Ishikawa iteration process, J. Math. Anal. Appl., 178(1993), 301-308.

[20] B.S. Thakur, R. Dewangan, M. Postolache, General composite implicit iteration process for a finite family of asymptotically pseudocontractive mappings, Fixed Point Theory Appl., 2014, Article ID 90.

[21] B.S. Thakur, M. Postolache, Existence and approximation of solutions for generalized extended nonlinear variational inequalities, J. Inequal. Appl., 2013, Article ID 590.

[22] B.S. Thakur, D. Thakur, M. Postolache, New iteration scheme for numerical reckoning fixed points of nonexpansive mappings, J. Inequal. Appl., 2014, Article ID 328.

[23] Y. Yao, M. Postolache, Iterative methods for pseudomonotone variational inequalities and fixed point problems, J. Optim. Theory Appl., 155(2012), no. 1, 273-287.

[24] Y. Yao, M. Postolache, S.M. Kang, Strong convergence of approximated iterations for asymptotically pseudocontractive mappings, Fixed Point Theory Appl., 2014, Article ID 100.

Received: March 1st, 2016; Accepted: September 1st, 2016. 
